\title{
Comparative LCA of technology improvement opportunities for a 1.5-MW wind turbine in the context of an onshore wind farm
}

\author{
Matthew Ozoemena ${ }^{1} \cdot$ Wai M. Cheung ${ }^{2}$ (i) $\cdot$ Reaz Hasan ${ }^{2}$
}

Received: 17 August 2017 / Accepted: 17 November 2017 / Published online: 25 November 2017

(c) The Author(s) 2017. This article is an open access publication

\begin{abstract}
This paper presents life cycle assessment (LCA) results of design variations for a 1.5-MW wind turbine due to the potential for advances in technology to improve their performance. Five LCAs have been conducted for design variants of a 1.5-MW wind turbine. The objective is to evaluate potential environmental impacts per kilowatt hour of electricity generated for a 114-MW onshore wind farm. Results for the baseline turbine show that higher contributions to impacts were obtained in the categories of ozone depletion potential, marine aquatic eco-toxicity potential, human toxicity potential and terrestrial eco-toxicity potential compared to technology improvement opportunities (TIOs) 1-4. Compared to the baseline turbine, TIO 1 with advanced rotors and reduced tower mass showed increased impact contributions to abiotic depletion potential, acidification potential, eutrophication potential, global warming potential and photochemical ozone creation potential, and TIO 2 with a new tower concept involving improved tower height showed an increase in contributions to abiotic depletion potential, acidification potential and global warming potential. Additionally, lower contributions to all the environmental categories were observed for TIO 3 with drivetrain improvements using permanent magnet generators while increased contributions towards abiotic depletion potential and global warming potential were noted for TIO 4 which combines TIO 1, TIO 2 and TIO 3. A comparative LCA study of wind turbine design variations for a particular power rating has not been explored in the literature. This study presents new insight into the environmental implications related with projected wind turbine design advancements.
\end{abstract}

Keywords 1.5-MW wind turbine · LCA · Technology improvement opportunities · Wind farm · Electricity production · Potential technology advancements

\begin{tabular}{|c|c|c|}
\hline \multicolumn{3}{|c|}{ Abbrevations } \\
\hline \multicolumn{2}{|c|}{ ADP } & Abiotic depletion potential \\
\hline \multicolumn{2}{|c|}{ AP } & Acidification potential \\
\hline \multicolumn{2}{|c|}{ BOM } & Bill of materials \\
\hline \multicolumn{2}{|c|}{ CML } & $\begin{array}{l}\text { Centre of Environmental Science of Leiden } \\
\text { University }\end{array}$ \\
\hline \multicolumn{2}{|c|}{$\mathrm{EP}$} & Eutrophication potential \\
\hline \multicolumn{2}{|c|}{ FAETP } & Freshwater aquatic eco-toxicity potential \\
\hline \multicolumn{2}{|c|}{ GWP } & Global warming potential \\
\hline \multicolumn{2}{|c|}{ HTP } & Human toxicity potential \\
\hline \multicolumn{2}{|c|}{ IEC } & International Electrotechnical Commission \\
\hline \multicolumn{3}{|c|}{$\begin{array}{l}凶 \text { Wai M. Cheung } \\
\text { wai.m.cheung@northumbria.ac.uk }\end{array}$} \\
\hline 1 & \multicolumn{2}{|c|}{$\begin{array}{l}\text { Warwick Manufacturing Group, International Manufacturing } \\
\text { Centre, The University of Warwick, Coventry CV4 7AL, UK }\end{array}$} \\
\hline 2 & $\begin{array}{l}\text { Depa } \\
\text { Facul } \\
\text { Unive }\end{array}$ & $\begin{array}{l}\text { ent of Mechanical and Construction Engineering, } \\
\text { f Engineering and Environment, Northumbria } \\
\text { ty, Newcastle upon Tyne NE1 8ST, UK }\end{array}$ \\
\hline
\end{tabular}

ISO International Organisation for Standardisation

LCA Life cycle assessment

LCI Life cycle inventory

MAETP Marine aquatic eco-toxicity potential

NREL National Renewable Energy Laboratory

ODP Ozone depletion potential

POP Photochemical ozone creation potential

TETP Terrestrial eco-toxicity potential

TIO Technology improvement opportunities

TIO 1 TIO with advanced (enlarged) rotors using stiffer carbon fibre material and reduced tower mass

TIO 2 TIO with new tower concept using carbon fibre and power production at $100 \mathrm{~m}$ compared to $65 \mathrm{~m}$

TIO 3 TIO with drivetrain improvements using permanent magnet generators instead of copperwound rotors

TIO 4 Combination of TIO 1, TIO 2 and TIO 3 


\section{Introduction}

Concern about the effects of climate change and public awareness with regard to environmental impacts has increased considerably in recent years. Compared with fossil fuel-based electricity generation, wind energy has significantly lower environmental burdens and hence is well placed to contribute towards mitigating potential environmental impacts and the effects of climate change. Wind power uses the kinetic energy of the wind to produce electricity without directly producing any emissions or pollutants during the conversion process (Martínez et al. 2009; Shafiee et al. 2016). This does not, however, mean it is free of environmental impacts. There are environmental implications as a result of the manufacturing, operation and disposal processes during the life cycle of the wind turbine (Ozoemena et al. 2016; Simons and Cheung 2016). These environmental impacts have to be quantified in order to examine the potential for improvement to the processes and to compare the effects of energy production (Fokaides et al. 2014; Igliński et al. 2016; Lieberei and Gheewala 2017).

In recent years, there has been rapid growth in wind power use partly due to its perceived importance for sustainable development (Lund 2007; Weinzettel et al. 2009; Singh and Parida 2013; Glassbrook et al. 2014; Panagiotidou et al. 2016; Uihlein 2016). According to Lantz et al. (2012) and Allaei and Andreopoulos (2014), wind energy technology has steadily improved and costs have decreased. This shift to higher nominal power of wind turbines demonstrates the apparent technological progress. Chen et al. (2011) point out that to support the growth of wind farms, it is essential that the long-term sustainability of wind turbines is examined in order to allow policy makers make robust decisions to mitigate climate change.

Over the years, there have been numerous research studies reporting on the application of LCA to measure the environmental impacts of wind farms (Dolan and Heath 2012). A few of the most recent publications which are relevant to this study are summarised as follows:

\section{Wind farm studies based on geographical scope}

In existing LCA-related wind farm literature, there are several studies based on geographical scope. Oebels and Pacca (2013), for instance, shows a comparison of the results for the $\mathrm{CO}_{2}$ intensity of a wind turbine design on a Brazilian wind farm. They concluded that construction and operation phases could be neglected. Within the manufacturing process, the steel tower was identified as the main source responsible for more than half of the emissions.
Wang and Sun (2012) showed that large $\mathrm{CO}_{2}$ savings can be made in countries with large territories and wind potential as a result of a case study of wind turbine designs in four characteristic wind power plants (one in China and three in North America and Europe) with Vestas 1.65-, 3.0- and $850-\mathrm{kW}$ wind turbine models. Analysis of the case in China shows that $33 \%$ of $\mathrm{CO}_{2}$ emissions could be saved in the transport stage in large countries by the use of shorter alternative transportation routes. Ardente et al. (2008)'s analysis is based on a wind turbine design located on an Italian wind farm. The research shows that the largest environmental impacts caused by a wind farm are mainly due to the manufacturing of wind turbines and building works. These impacts principally consist of air emissions, inert solid wastes and small quantities of hazardous exhausted oils and lubricants. Other impacts are not significant.

\section{Studies on the effects of wind turbine size within a wind farm}

There are also studies on the effects of size of a turbine design within a wind farm (Crawford 2009; Raadal et al. 2011; Kabir et al. 2012; Demir and Taşkin 2013). In Crawford (2009), it is shown that advantages exist for the use of a 3-MW wind turbine compared to an $850-\mathrm{kW}$ turbine as a result of the ability to decrease the environmental footprint per unit of rated output. According to Raadal et al. (2011), there is evidence of GHG emissions and energy use decreasing with increase in the size of wind turbines. Demir and Taşkin (2013) provide useful evidence that environmental impacts are lower for larger turbines (2050 and $3020 \mathrm{~kW})$ compared to smaller turbines (330, 500 and $810 \mathrm{~kW})$ and could be further reduced by installation in optimum wind speed regions. Kabir et al. (2012) and Ardente et al. (2008) used the LCA technique to analyse existing wind farms with small-scale wind turbine designs (100 and $660 \mathrm{~kW})$ and focused on energy requirement and environmental impact analyses. It was observed that turbine production, transportation and installation were the stages that most affected the life cycle energy and emissions of small wind power.

\section{Future-inclined studies on wind farms}

In addition, there are also other studies focused on futureinclined analysis as for instance Pehnt et al. (2008), Arvesen and Hertwich (2011), Lenzen and Schaeffer (2012). They all focused on scenario-based assessment analysed towards a future time frame. Arvesen and Hertwich (2011) presents a global scenario-based assessment that estimates $3.5 \mathrm{Gt} \mathrm{CO}_{2} \mathrm{e}$ emitted as a result of operating and building wind farms using turbine designs with current technology and turbines with potential technological advancements in the time frame 
between 2007 and 2050 to supply $22 \%$ of electricity worldwide by 2050 . A cohesive life cycle modelling of cumulative avoided emissions is also included in the same study. The results show that emissions avoided by wind energy exceed emissions caused by wind energy. In Lenzen and Schaeffer (2012), avoided and caused climate change impacts of eight energy technologies are analysed towards year 2100 . The main aim was to show differences between temperaturebased indicators for climate change mitigation potential and emissions.

\section{Literature summary and the proposed approach}

In summary, the recent literature shows that wind turbine design on a wind farm can contribute to potential increased energy production and environmental impacts. This concluding remark is also supported by one of Bai et al. (2016)'s findings that environmental impacts for onshore and offshore wind power technologies will depend on a wind farm's siting circumstances, turbine size and turbine/wind farm design.

In this proposed study, the main differentiating component is the presentation of an LCA study to evaluate the environmental impacts for a wind farm using an existing turbine and four different potential design variants for a $1.5-\mathrm{MW}$ wind turbine while considering most of the life cycle stages. LCA is used because it is a fairly detailed tool for a specific type of comparison, i.e. of alternative product systems. However, other environmental management techniques such as risk assessment, environmental performance evaluation, environmental auditing and environmental impact assessment deal with a broader set of comparisons and seem to put slightly more emphasis on the organisation of the process of decision-making. ISO 14040 standard (ISO 2006a, b) is applied allowing quantification of the overall impacts for each turbine design on the wind farm. This study also allows for an analysis of the issues that are the basis for higher environmental impacts as well as aspects that could be developed in order to decrease negative impacts. The LCA models have been developed with the purpose of quantifying and determining the related emissions as well as the impacts of the use of wind energy technology.

\section{Methods}

\section{Goal and scope}

Five LCAs for a 1.5-MW wind turbine has been conducted in accordance with ISO 14040/44 standards (ISO 2006a, b). The goal of the LCAs is an evaluation of the potential environmental impacts associated with electricity production from a 114-MW onshore wind farm comprised of design variants for a $1.5-\mathrm{MW}$ wind turbine. The turbine has been mainly designed to operate under low wind conditions, thus having an IEC $3 \mathrm{~A}$ wind class. The studies consider a representative wind farm layout based on information collected from databases as well as external sources. The system boundary of the assessed wind farm is shown in Fig. 1.

The LCAs assess most stages of the life cycle from cradle to grave, including raw materials production, component manufacture, transportation of components and site erection, replacement of parts and operations and dismantling at the end of life.

\section{Case studies}

The 1.5-3 MW range of turbines is one of the most common turbine ratings installed globally (Lantz et al. 2012). Hence to model potential technological advancements in wind turbine technology, projections were based on future technological designs due to scientific developments and research based on National Renewable Energy Laboratory (NREL) 1.5-MW wind turbine technology forecasting studies (Cohen et al. 2008; Lantz et al. 2012). The reports detail an analytical approach for an assessment of the potential for technological progress in Low Wind Speed Technology under the US Department of Energy's Wind Energy Program. The section below presents a summary of the potential for advances in technology to increase the performance of a 1.5-MW wind turbine.
Fig. 1 Boundary for the life cycle of the wind farm

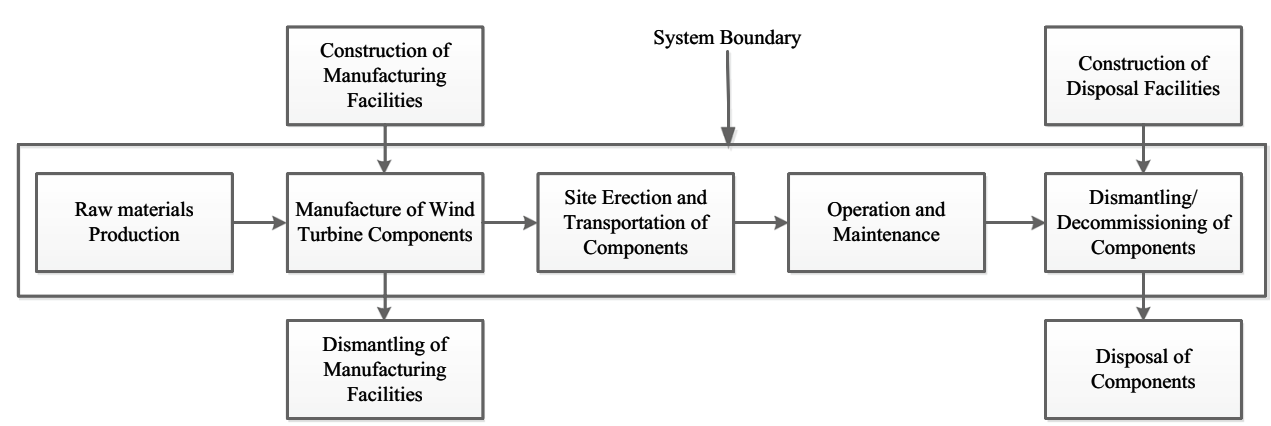




\section{Baseline turbine description}

The NREL's baseline turbine technology attributes represent a variable-pitch, upwind, three-bladed, variable-speed turbine that uses a doubly fed 1.5-MW-rated generator. The rotor diameter is $70 \mathrm{~m}$, and the tower height is $65 \mathrm{~m}$. Hence, an Enercon E-66 1.5-MW turbine was chosen as the baseline 1.5-MW wind turbine technology as it shares similar technical characteristics to the NREL baseline turbine. Table 1 shows the technical summary of the Enercon E-66 1.5-MW turbine.

\section{Technology improvement opportunities (TIOs)}

According to Cohen et al. (2008), wind turbine design is a matter of continuous compromise between the competing demands of increased durability and lifetime, maintenance cost, overall cost optimisation and greater energy productivity. These designers' trade-offs are captured in the model. Details of the TIOs are summarised in Table 2.

\section{Mass scaling equations}

Scaling equations taken from an NREL study (Fingersh et al. 2006) were used to generate material quantities for the different TIO's. The equations used in this study are defined in Table 3 as well as an indication as to where they were employed.

\section{Functional unit}

The functional unit used for this LCA study is "the generation of $1 \mathrm{kWh}$ of electricity delivered to the grid by a wind farm". This is based on the wind farm operational lifetime of 25 years (Nuon 2009) and the total electricity generation based on estimated wind resource for the location of
Table 1 Technical characteristics of Enercon E-66 (Papadopoulos 2010)

\begin{tabular}{ll}
\hline Model & Enercon E-66 \\
\hline Rated capacity & $1.5 \mathrm{MW}$ \\
Rotor diameter & $70 \mathrm{~m}$ \\
Hub height & $65 \mathrm{~m}$ \\
Swept area & $3421 \mathrm{~m}^{2}$ \\
Converter concept & Gearless, variable speed, variable blade pitch \\
Rotor with pitch control & Upwind rotor with active pitch control \\
Number of blades & 3 \\
Rotor speed & Variable, 10-22 rpm \\
Tip speed & $35-76$ m/s \\
Pitch control & Three synchronised blade pitch systems with emergency supply \\
Generator & Direct-driven Enercon synchronous ring generator \\
Grid feeding & Enercon inverter \\
Braking system & Three independent pitch control systems with emergency supply \\
\hline
\end{tabular}

Table 2 Potential contributions to wind turbine performance improvement

\begin{tabular}{|c|c|c|}
\hline $\begin{array}{l}\text { Performance } \\
\text { improvement }\end{array}$ & Technology pathway & Description \\
\hline TIO 1 & Advanced (enlarged) rotors & $\begin{array}{l}\text { Stiffer carbon fibre materials allowing for } 25 \% \text { rotor growth and } 2 \% \text { reduction in tower mass. This } \\
\text { TIO uses the approach of enlarging the rotor to increase the energy capture in ways that do not } \\
\text { increase structural loads or electrical power equipment requirements }\end{array}$ \\
\hline TIO 2 & Advanced tower concepts & $\begin{array}{l}\text { New tower concepts using carbon fibre materials and power production at } 100 \mathrm{~m} \text { compared to } 65 \mathrm{~m} \text {. } \\
\text { This TIO is based on the use of new tower concepts that will enable taller towers to be erected in } \\
\text { more difficult locations, without the use of high lift capacity cranes and may allow the tower to be } \\
\text { assembled (and possibly even fabricated) on site, thereby reducing the cost of tower transport as } \\
\text { well as increase the energy capture }\end{array}$ \\
\hline TIO 3 & Drivetrain improvements & $\begin{array}{l}\text { Permanent magnet generators that use permanent magnets instead of copper-wound rotors. This TIO } \\
\text { is based on the use of a generator spinning at } 150 \mathrm{rpm} \text {, compared to } 1200-1800 \mathrm{rpm} \text { for normal } \\
\text { induction generators. This generator design is coupled with a single-stage gearbox that is much } \\
\text { more compact and less complex (fewer gears and bearings) than multi-stage gearboxes used in } \\
\text { most wind turbines today }\end{array}$ \\
\hline TIO 4 & Fully combined TIO's & A combination of all the potential technological advancements \\
\hline
\end{tabular}


Table 3 Mass scaling equations for the different components

\begin{tabular}{|c|c|c|c|}
\hline Component & Equation & Description & $\begin{array}{l}\text { Total weight of main compo- } \\
\text { nents for baseline turbine and } \\
\text { TIOs }\end{array}$ \\
\hline Blade & Advanced:Mass $=0.4948 \times R^{2.53}$ per blade & $\begin{array}{l}\text { Where } R=\text { rotor radius. The advanced blade mass } \\
\text { relationship follows products developed by a wind } \\
\text { turbine blade manufacturer which "represents com- } \\
\text { binations of technology enhancements that may } \\
\text { not/may include carbon and takes advantage of a } \\
\text { lower-weight root design" }\end{array}$ & $\begin{array}{l}\text { Baseline turbine }=16,152 \mathrm{~kg} \\
\text { TIO } 1=21,049 \mathrm{~kg} \\
\text { TIO } 2=16,152 \mathrm{~kg} \\
\text { TIO } 3=16,152 \mathrm{~kg} \\
\text { TIO } 4=21,049 \mathrm{~kg}\end{array}$ \\
\hline Tower & $\begin{array}{l}\text { Advanced:Mass }=0.2694 \times \text { swept area } \times \\
\text { hub height }+1779\end{array}$ & $\begin{array}{l}\text { The baseline case is based on conventional technol- } \\
\text { ogy for } 2002 \text {, while the advanced case represents } \\
\text { advanced technologies including reduced blade } \\
\text { solidity in conjunction with higher tip speeds, flap- } \\
\text { twist coupling in the blade and tower feedback in } \\
\text { the control system }\end{array}$ & $\begin{array}{l}\text { Baseline turbine }=153,094 \mathrm{~kg} \\
\text { TIO } 1=150,032 \mathrm{~kg} \\
\text { TIO } 2=93,941 \mathrm{~kg} \\
\text { TIO } 3=153,094 \mathrm{~kg} \\
\text { TIO } 4=93,941 \mathrm{~kg}\end{array}$ \\
\hline Powertrain & Mass $=10.51 \times$ machine rating ${ }^{0.9223}$ & $\begin{array}{l}\text { A generator mass calculation for the medium-speed } \\
\text { permanent magnet generator design was based on } \\
\text { machine power rating in } \mathrm{kW} \text {. }\end{array}$ & $\begin{array}{l}\text { Baseline turbine }=40,690 \mathrm{~kg} \\
\text { TIO } 1=40,690 \mathrm{~kg} \\
\text { TIO } 2=40,690 \mathrm{~kg} \\
\text { TIO } 3=8931 \mathrm{~kg} \\
\text { TIO } 4=8931 \mathrm{~kg}\end{array}$ \\
\hline
\end{tabular}

Where rotor radius $(R)$ is in metres, swept area is in $\mathrm{m}^{2}$, hub height is in metres and machine rating is in $\mathrm{kW}$

the wind farm. Information about the wind farm is given in Table 4.

Using the analytical wind data, the assumptions above and assuming 3000 actual load hours per year, the annual energy output of the modelled wind farm (using the baseline turbine, TIO 1 and TIO 3) was estimated to be $212 \mathrm{GWh} / \mathrm{a}$ yielding a capacity factor of $21 \%$. Modelling the wind farm using TIO 2 and TIO 4, annual energy output was estimated to be $215 \mathrm{GWh} / \mathrm{a}$ with a capacity factor of $22 \%$.

\section{Data collection and wind farm life cycle modelling}

Wind turbines consist of many components and sub-components with different electrical and mechanical parts, and hence, information on all the parts that compose a turbine is difficult to gather. For this study, the wind turbine life cycle inventory (LCI) data were focused on the most important components, specifically the blades, tower, generator, rest of the nacelle, grid connection and foundations. In cases where the material data were not found during the life cycle modelling, alternative material data from the Ecoinvent database (V.2.2) has been used. The energy requirements used in the various life cycle stages have been incorporated into the model using data provided in Chataignere and Boulch (2003). Transport distances have been calculated from Google Maps (2014) and SeaRates (2014). The main materials constituting the components of the turbine can be seen in "Appendix" (Table 9).

\section{Raw materials and production}

Life cycle modelling begins with the bill of materials (BOM) containing the main components of the wind turbine. In the LCA models, the manufacturing processes, material datasets and country of origin are assigned to each component to build comprehensive models of the baseline
Table 4 General data about the wind farm

\begin{tabular}{|c|c|c|}
\hline Wind farm location & & Pen y Cymoedd, South Wales, UK \\
\hline Wind class & & IEC3A \\
\hline Rated output (MW) & 114 & Installed capacity of the wind farm \\
\hline \multirow[t]{2}{*}{$\begin{array}{l}\text { Gross annual energy output per } \\
\text { turbine }\end{array}$} & $\begin{array}{l}\text { Baseline turbine, TIO } 1 \text { and } \\
\text { TIO } 3\end{array}$ & $3.36 \mathrm{GWh} / \mathrm{a}$ \\
\hline & TIO 2 and TIO 4 & $3.4 \mathrm{GWh} / \mathrm{a}$ \\
\hline Number of turbines & 76 & $\begin{array}{l}\text { The number of wind turbines on the } \\
\text { farm connected to one transition } \\
\text { station }\end{array}$ \\
\hline Power loss assumption & & $17 \%$ \\
\hline Nominal power (MW) & 1.5 & Nominal power of one wind turbine \\
\hline
\end{tabular}


turbine and TIOs 1-4. The component and material data for the baseline turbine were taken from Papadopoulos (2010). Over $99.5 \%$ of the total mass of the baseline turbine and TIOs 1-4 were mapped. Consequently, the LCA model for the wind farm consisted of 456 components as well as additional manufacture, assembly and disassembly processes. The raw materials were modelled using a recycled content approach (for metals) based on the average production datasets from Ecoinvent. This allows results for individual materials, manufacturing processes and components to be analysed to a high degree of detail. Table 5 details the assumptions used in modelling components of the Enercon E-66 wind turbine and TIOs 1-4.

\section{Energy requirements for wind turbine manufacture, assembly and dismantling}

Chataignere and Boulch (2003) provided data on the energy requirements for the manufacture, assembly and dismantling of a 1.5-MW wind turbine. It specified the total primary energy requirement to be $379,734 \mathrm{MJ}$ based on an even split between gas and electricity. Natural gas inputs were given as $2625 \mathrm{~m}^{3}$ and electricity requirements given as $26.3 \mathrm{MWh}$. The end of life of the turbine is assumed to require the same energy inputs. The "electricity, medium voltage, production RER, at grid/RER U" option of the Ecoinvent database is the electricity mix considered in order to best represent average European electricity production.

\section{Site work}

This covers the energy and material requirements during the construction of the wind farm. Estimates and assumptions had to be made for this section as there was little available data. The necessary inputs were separated into two categories: inputs related to component transportation from the manufacturing facilities to the site and the inputs related to construction work at the site required to make the wind farm operational.

\section{Component transportation}

The wind farm is situated within the Coed Morgannwg Strategic Search Area, South Glamorgan in Wales, UK, and the assumed location of major component production is Aurich, Germany. It is necessary to define the likely transportation routes of the components in order to determine the transportation requirements for construction of the wind farm. As no data existed describing the exact arrival port for the components, assumptions were made as regards the most likely route. The components of the wind turbine are assumed to be transported from the manufacturing facilities in Magdeburg, southern Germany, to Hamburg port, north Germany. Assumed to be covered by road (40t truck), the distance is given as $281 \mathrm{~km}$ requiring about nine trips to deliver one unit of 1.5-MW wind turbine. From Hamburg, the components are then assumed to be transported by container ship to the port of Swansea in Wales, a distance estimated to be about $1277 \mathrm{~km}$ (SeaRates 2014). The components are then

Table 5 Assumptions used in modelling components of Enercon E-66 wind turbine and TIOs 1-4

\begin{tabular}{|c|c|c|}
\hline Component & Assumptions for material breakdown & Rationale \\
\hline Nacelle & Undefined material omitted & Undefined material omitted as it is within the cut-off criteria \\
\hline $\begin{array}{l}\text { Grid connection and } \\
\text { control mechanism }\end{array}$ & $\begin{array}{l}\text { Generic entries were used to cover range of electrical } \\
\text { components }\end{array}$ & $\begin{array}{l}\text { No clear distinction in the difference between electrical } \\
\text { components }\end{array}$ \\
\hline \multirow[t]{2}{*}{ Blades } & Undefined material entry replaced by iron & $\begin{array}{l}\text { Used to represent material requirements for parts such as } \\
\text { brackets, bolts }\end{array}$ \\
\hline & $\begin{array}{l}\text { For TIO } 1 \text { and } 4 \text {, fibre glass material used in the baseline } \\
\text { turbine is replaced by glass-reinforced nylon }\end{array}$ & $\begin{array}{l}\text { Glass-reinforced nylon is used in place of carbon fibre as it } \\
\text { was the closest possible material flow entry in Ecoinvent. } \\
\text { Duflou et al. (2012) and Howarth et al. (2014), however, } \\
\text { note that carbon fibre generally has higher cumulative } \\
\text { energy demand and greenhouse gas emission values com- } \\
\text { pared to glass-reinforced nylon. }\end{array}$ \\
\hline Tower & $\begin{array}{l}\text { For TIO } 2 \text { and TIO 4, steel used in the baseline turbine is } \\
\text { replaced by glass-reinforced nylon }\end{array}$ & $\begin{array}{l}\text { Glass-reinforced nylon is used in place of carbon fibre as it } \\
\text { was the closest possible material flow entry in Ecoinvent. } \\
\text { Duflou et al. (2012) and Howarth et al. (2014), however, } \\
\text { note that carbon fibre generally has higher cumulative } \\
\text { energy demand and greenhouse gas emission values com- } \\
\text { pared to glass-reinforced nylon. }\end{array}$ \\
\hline \multirow[t]{2}{*}{ Generator } & $\begin{array}{l}\text { For TIO 3, copper used in the baseline turbine is replaced } \\
\text { with iron }\end{array}$ & As stated in scenario definition \\
\hline & Undefined materials omitted from model & They account for only $1.2 \%$ of generator mass \\
\hline Foundation & No assumptions required & No undefined materials \\
\hline
\end{tabular}


transported by road (40t truck) to their destination at the Pen y Cymoedd wind farm site, a distance approximated to be $47 \mathrm{~km}$. It should be pointed out that the foundations are assumed to be sourced locally and hence are not included as part of the components transported from Germany.

\section{On-site energy requirements}

For construction on site, the use of heavy machinery is required for the wind farm. For the purpose of this study, hydraulic diggers (for preparing the foundations of the wind turbine) and cranes (for erecting the turbines) are assumed to be the main contributors during site construction. According to Elsam Engineering (2004), each wind turbine requires the removal of approximately $450 \mathrm{~m}^{3}$ of earth. In Rydh et al. (2004), the installation of a wind turbine is assumed to require approximately $16 \mathrm{~h}$ of crane work. Chataignere and Boulch (2003) provided data on on-site energy requirements which was given as $556 \mathrm{MJ}$ for one unit of turbine. This was used to represent diesel for the building machines.

\section{Wind farm operation}

The operation stage of the wind farm encompasses requirements for keeping the wind farm operational over its lifetime. For the modelling process, some assumptions had to be made as regards the nature of maintenance to be carried out.

\section{Component replacement}

Wear and tear, especially of the rotating components, will occur during operation of the wind turbines. The lifetime of the wind farm modelled in this study is 25 years (Nuon 2009). To be safe, a conservative estimate for maintenance of turbines on the wind farm is assumed based on assumptions in Vestas (2006). Hence during the lifetime of a wind farm, one renewal of half of the generators or the gearboxes must be carried out which is expected to, as a minimum, comprise renewal of the bearings. For the purpose of this study, this assumption was simplified to be a total renewal of half of the generators once in the lifetime of the wind farm.

\section{Oils and lubricants}

According to D'Souza et al. (2011), wind turbines require a replacement of lubricant and oils on a regular basis. In this study, two assumptions are made based on data in Rydh et al. (2004) and Vestas (2006). Both studies state that each wind turbine requires 3201 of gear oil for every 5 years of operation and the lubrication requirements for each wind turbine is $16 \mathrm{~kg} / \mathrm{a}$.

\section{Inspection and maintenance}

The use of a hydraulic crane was added to the modelling process to simulate the actual inspection procedure. To replace the generators, the assumption in Rydh et al. (2004) that each turbine required crane use for $8 \mathrm{~h}$ was used. Inspection requirements were also based on Rydh et al. (2004)'s assumption that every 6 months, a maintenance van would inspect the site. The distance travelled for the inspection procedure is assumed to be $120 \mathrm{~km}$ based on a round trip from the operations base to the wind farm.

\section{Wind farm decommissioning}

There is insufficient information about this life cycle stage of wind farms as few wind farms have actually been decommissioned up to now. There are, however, data on the theoretical disposal of wind turbines to enable the modelling of this stage. The turbines are assumed to be disassembled using a mobile crane and transported $500 \mathrm{~km}$ by road (40t truck) to a disposal facility requiring another nine trips to transport one unit of 1.5-MW wind turbine. Energy requirements for dismantling at the facility are assumed to be $2625 \mathrm{~m}^{3}$ of natural gas and 26.3 MWh of electricity as stated in Chataignere and Boulch (2003). The foundations of the turbines are assumed to be left behind on the wind farm site. As already shown in Fig. 1, the influence of recycling components of the wind farm was not included in this study. Recycling credit is not given at end of life because a recycled content approach has been taken.

\section{Cut-off criteria}

The cut-off criteria given below were used to make certain that all relevant possible environmental impacts were represented:

- Energy - if a flow is less than $1 \%$ of the energy at a product level, then it may be excluded, provided its environmental relevance is not a concern.

- Mass-if a flow is less than $1 \%$ of the mass at a product level, then it may be excluded, provided its environmental relevance is not of concern.

- Environmental relevance-if a flow meets the above exclusion criteria, but is considered to possibly have a significant environmental impact, it should be included. All material flows leaving the system (emissions) and whose environmental impact is higher than $1 \%$ of the whole impact of an impact category that has been considered in the assessment should be included.

- The sum of the neglected material flows should not exceed $5 \%$ of total energy, mass or environmental relevance, at a product level. 


\section{Allocation}

According to ISO (ISO 2006a, b) requirements, allocation has been avoided in this study since the production of electricity is considered as the only function of the system. Allocation was therefore not considered for any process or component.

\section{Results}

This section addresses the environmental implications of the LCA using the different wind turbine design variations in the wind farm model. There are different impact assessment methods principally based on the problem-oriented (midpoint) and damage-oriented (end-point) impact categories. All environmental indicators have been estimated using the Centre of Environmental Science of Leiden University CML 2001 impact assessment methodology (Guinée 2002) which focuses on midpoints of the cause-effect chain. The CML method was chosen because it has been used in previous wind farm LCAs to give robust results for mid-point potential impacts as well as to enable comparison. Contributions to impacts of the different design variations are presented and discussed in the following sections. Full results of the total impacts and contribution analysis of the life cycle stages can be found in Tables 6 and 7 .

\section{Life cycle impact assessment}

The following section gives an overview of the main contributors to each environmental impact category.

Abiotic depletion potential (ADP) The lowest ADP value observed is $7.98 \mathrm{E}-05 \mathrm{~kg} \mathrm{Sb}$ eq./ $/ \mathrm{kWh}$ for TIO 3 and the highest observed ADP value is $1.26 \mathrm{E}-04 \mathrm{~kg}$ Sb eq. $/ \mathrm{kWh}$ for TIO 2. This impact mainly relates to the depletion of energy used (in the form of coal, natural gas and crude oil) in glassreinforced nylon production as well as production of highalloy steels in the nacelle, generator and grid connection.

Acidification potential (AP) The minimum AP value obtained is $5.89 \mathrm{E}-05 \mathrm{~kg} \mathrm{SO}$ eq. $/ \mathrm{kWh}$ for TIO 3 and the maximum observed AP value is $1.06 \mathrm{E}-04 \mathrm{~kg} \mathrm{SO}_{2}$ eq. $/ \mathrm{kWh}$ for TIO 2. This impact primarily relates to production of the tower and foundations. The emissions to air of nitrogen oxides and sulphur dioxide associated with the production of iron, steel and glass-reinforced nylon are the primary contributing substances.

Eutrophication potential (EP) The lowest EP value observed is $3.42 \mathrm{E}-05 \mathrm{~kg} \mathrm{PO}_{4}$ eq./ $/ \mathrm{kWh}$ for TIO 4 and the highest observed EP value is $6.91 \mathrm{E}-05 \mathrm{~kg} \mathrm{PO}_{4}$ eq. $/ \mathrm{kWh}$ for TIO 1. The main turbine components contributing to EP are tower and foundation. The primary substances contributing to EP are the emissions to air and water of nitrogen oxides and phosphate.

Global warming potential (GWP) The minimum GWP value obtained is $1.03 \mathrm{E}-02 \mathrm{~kg} \mathrm{CO}_{2}$ eq./kWh for TIO 3 and the maximum observed GWP value is $1.66 \mathrm{E}-02 \mathrm{~kg} \mathrm{CO}_{2}$ eq./ $\mathrm{kWh}$ for TIO 2. The emissions to air of carbon dioxide and methane are the main contributing substances which result from fuel combustion largely during production of steel and glass-reinforced nylon for the turbine.

Ozone depletion potential $(O D P)$ The lowest ODP value observed is $7.86 \mathrm{E}-10 \mathrm{~kg}$ CFC- 11 eq. $/ \mathrm{kWh}$ for TIO 4 and the highest observed ODP value is $1.24 \mathrm{E}-09 \mathrm{~kg}$ CFC- 11 eq./ $\mathrm{kWh}$ for the baseline turbine. Emissions of non-methane volatile organic compound (NMVOCs), i.e. halons 1001, 1211 and 1301 during production of fiberglass, steel, concrete and transportation of components, are the major contributors to this impact.

Human toxicity potential (HTP) The minimum HTP value obtained is $2.31 \mathrm{E}-02 \mathrm{~kg} 1,4-\mathrm{DB}$ eq./ $/ \mathrm{kWh}$ for TIO 4 and the maximum observed HTP value is $5.38 \mathrm{E}-02 \mathrm{~kg}$ 1,4-DB eq./

Table 6 Life cycle environmental impacts per $\mathrm{kWh}$ of the wind farm using the different turbine design variations

\begin{tabular}{|c|c|c|c|c|c|}
\hline Impact categories (unit) & Baseline turbine & $\begin{array}{l}\text { TIO } 1 \text { advanced } \\
\text { (enlarged) Rotors }\end{array}$ & $\begin{array}{l}\text { TIO } 2 \text { advanced tower } \\
\text { concepts }\end{array}$ & $\begin{array}{l}\text { TIO } 3 \text { drivetrain } \\
\text { improvements }\end{array}$ & $\begin{array}{l}\text { TIO } 4 \text { fully } \\
\text { combined } \\
\text { TIO's }\end{array}$ \\
\hline $\mathrm{ADP}(\mathrm{kg} \mathrm{Sb})$ eq. & $8.91 \mathrm{E}-05$ & $9.49 \mathrm{E}-05$ & $1.26 \mathrm{E}-04$ & $7.98 \mathrm{E}-05$ & $1.22 \mathrm{E}-04$ \\
\hline $\mathrm{AP}\left(\mathrm{kg} \mathrm{SO}_{2}\right)$ eq. & $9.17 \mathrm{E}-05$ & $9.39 \mathrm{E}-05$ & $1.06 \mathrm{E}-04$ & $5.89 \mathrm{E}-05$ & $7.74 \mathrm{E}-05$ \\
\hline $\mathrm{EP}\left(\mathrm{kg} \mathrm{PO}_{4}\right)$ eq. & $6.90 \mathrm{E}-05$ & $6.91 \mathrm{E}-05$ & $6.46 \mathrm{E}-05$ & $3.69 \mathrm{E}-05$ & $3.42 \mathrm{E}-05$ \\
\hline $\left.\mathrm{GWP}(\mathrm{kg} \mathrm{CO})_{2}\right)$ eq. & $1.18 \mathrm{E}-02$ & $1.25 \mathrm{E}-02$ & $1.66 \mathrm{E}-02$ & $1.03 \mathrm{E}-02$ & $1.59 \mathrm{E}-02$ \\
\hline $\mathrm{ODP}$ (kg CFC) eq. & $1.24 \mathrm{E}-09$ & $1.23 \mathrm{E}-09$ & $9.18 \mathrm{E}-10$ & $1.11 \mathrm{E}-09$ & $7.86 \mathrm{E}-10$ \\
\hline HTP (kg 1,4DB) eq. & $5.38 \mathrm{E}-02$ & $5.35 \mathrm{E}-02$ & $5.08 \mathrm{E}-02$ & $2.51 \mathrm{E}-02$ & $2.31 \mathrm{E}-02$ \\
\hline FAETP (kg 1,4-DB) eq. & $1.95 \mathrm{E}-02$ & $1.95 \mathrm{E}-02$ & $1.66 \mathrm{E}-02$ & $1.04 \mathrm{E}-02$ & $8.01 \mathrm{E}-03$ \\
\hline MAETP (kg 1,4-DB) eq. & 44.8 & 44.7 & 40.1 & 21.1 & 17.3 \\
\hline TETP (kg 1,4-DB) eq. & $2.24 \mathrm{E}-04$ & $2.23 \mathrm{E}-04$ & $1.61 \mathrm{E}-04$ & $1.51 \mathrm{E}-04$ & $8.72 \mathrm{E}-05$ \\
\hline POP $\left(\mathrm{kg} \mathrm{C}_{2} \mathrm{H}_{4}\right)$ eq. & $6.54 \mathrm{E}-06$ & $6.62 \mathrm{E}-06$ & $5.92 \mathrm{E}-06$ & $4.95 \mathrm{E}-06$ & $4.54 \mathrm{E}-06$ \\
\hline
\end{tabular}


Table 7 Percentage contribution of the different stages to the life cycle impacts of the farm

\begin{tabular}{|c|c|c|c|c|c|c|}
\hline $\begin{array}{l}\text { Impact catego- } \\
\text { ries }(\%)\end{array}$ & Life cycle stage & Baseline turbine & TIO 1 & TIO 2 & TIO 3 & TIO 4 \\
\hline \multirow[t]{3}{*}{ ADP } & Construction & 89.1 & 89.8 & 93.1 & 92.2 & 95.6 \\
\hline & Operation & 6.1 & 5.8 & 4.1 & 2.8 & 1.7 \\
\hline & Decommissioning & 4.8 & 4.4 & 2.8 & 5.0 & 2.7 \\
\hline \multirow[t]{3}{*}{ AP } & Construction & 83.6 & 84.0 & 87.0 & 93.4 & 95.7 \\
\hline & Operation & 12.9 & 12.6 & 10.6 & 1.6 & 1.2 \\
\hline & Decommissioning & 3.5 & 3.4 & 2.4 & 5.0 & 3.1 \\
\hline \multirow[t]{3}{*}{ EP } & Construction & 82.8 & 82.9 & 82.6 & 97 & 97.0 \\
\hline & Operation & 16.3 & 16.2 & 16.6 & 1.4 & 1.5 \\
\hline & Decommissioning & 0.9 & 0.9 & 0.8 & 1.6 & 1.5 \\
\hline \multirow[t]{3}{*}{ GWP } & Construction & 88.6 & 89.2 & 92.6 & 92.1 & 95.5 \\
\hline & Operation & 6.8 & 6.4 & 4.6 & 2.9 & 1.8 \\
\hline & Decommissioning & 4.6 & 4.4 & 2.8 & 5.0 & 2.7 \\
\hline \multirow[t]{3}{*}{ ODP } & Construction & 60.6 & 60 & 58.6 & 62.8 & 60.1 \\
\hline & Operation & 3.5 & 3.6 & 4.56 & 1.3 & 1.8 \\
\hline & Decommissioning & 35.9 & 36.4 & 36.9 & 35.9 & 38.1 \\
\hline \multirow[t]{3}{*}{ HTP } & Construction & 81.6 & 81.5 & 81.5 & 98.8 & 98.9 \\
\hline & Operation & 18.0 & 18.1 & 18.2 & 0.4 & 0.4 \\
\hline & Decommissioning & 0.4 & 0.4 & 0.3 & 0.8 & 0.7 \\
\hline \multirow[t]{3}{*}{ FAETP } & Construction & 83.4 & 83.4 & 81.5 & 98.1 & 97.7 \\
\hline & Operation & 16.2 & 16.2 & 18.2 & 1.3 & 1.6 \\
\hline & Decommissioning & 0.4 & 0.4 & 0.3 & 0.6 & 0.7 \\
\hline \multirow[t]{3}{*}{ MAETP } & Construction & 81.5 & 81.5 & 80.3 & 98.2 & 98.0 \\
\hline & Operation & 18.1 & 18.1 & 19.3 & 0.9 & 1.1 \\
\hline & Decommissioning & 0.4 & 0.4 & 0.4 & 0.9 & 0.9 \\
\hline \multirow[t]{3}{*}{ TETP } & Construction & 88.5 & 88.3 & 84.7 & 99.1 & 98.7 \\
\hline & Operation & 11.0 & 11.2 & 14.7 & 0.2 & 0.3 \\
\hline & Decommissioning & 0.5 & 0.5 & 0.6 & 0.7 & 1.0 \\
\hline \multirow[t]{3}{*}{ POP } & Construction & 87.2 & 87.4 & 87.1 & 94.1 & 94.5 \\
\hline & Operation & 9.4 & 9.3 & 10.0 & 1.9 & 2.0 \\
\hline & Decommissioning & 3.4 & 3.3 & 2.9 & 4.0 & 3.5 \\
\hline
\end{tabular}

$\mathrm{kWh}$ for the baseline turbine. The main contributing substances to HTP are the release to air and water of heavy metals such as antimony and arsenic which result from the production of stainless steel materials.

Freshwater aquatic eco-toxicity potential (FAETP) The lowest FAETP value observed is $8.00 \mathrm{E}-03 \mathrm{~kg} 1,4-\mathrm{DB}$ eq./ $\mathrm{kWh}$ for TIO 4 and the highest observed FAETP value is 1.95E-02 kg 1,4-DB eq./kWh for the baseline turbine and TIO 1. The production of polymer materials (polyethylene and PVC) resulting in the emission of benzo(a)pyrene to freshwater is the major contributor to this impact. Other contributing substances are related to the release of heavy metals to water such as copper, zinc, beryllium and nickel.

Marine aquatic eco-toxicity potential (MAETP) The minimum MAETP value obtained is $17.3 \mathrm{~kg} 1,4-\mathrm{DB}$ eq./ $\mathrm{kWh}$ for TIO 4 and the maximum observed MAETP value is $44.8 \mathrm{~kg} 1,4-\mathrm{DB}$ eq./ $\mathrm{kWh}$ for the baseline turbine. The impacts towards MAETP are primarily due to emissions of heavy metals to air and water which result, for example, from the production of stainless steel materials.

Terrestrial eco-toxicity potential (TETP) The lowest TETP value observed is $8.70 \mathrm{E}-05 \mathrm{~kg} 1,4-\mathrm{DB}$ eq./ $\mathrm{kWh}$ for TIO 4 and the highest observed TETP value is $2.24 \mathrm{E}-04 \mathrm{~kg}$ 1,4-DB eq./kWh for the baseline turbine. The impacts towards TETP are primarily driven by the release of heavy metals to air, soil and water relating mainly to arsenic, mercury and chromium. These emissions are as a result of the production of metals used in the turbine, mainly steel and stainless steels.

Photochemical ozone creation potential $(P O P)$ The minimum POP value obtained is $4.50 \mathrm{E}-06 \mathrm{~kg} \mathrm{C}_{2} \mathrm{H}_{4}$ eq./ $\mathrm{kWh}$ for TIO 4 and the maximum observed POP value is $6.62 \mathrm{E}-06 \mathrm{~kg} \mathrm{C}_{2} \mathrm{H}_{4}$ eq./kWh for TIO 1 . The main contributing substances to this impact are carbon monoxide, benzene, butane and ethane from aluminium and steel production processes. 


\section{Life cycle impacts}

Characterised life cycle environmental impact results of the wind farm for the baseline turbine in comparison with TIOs 1-4 are given in Fig. 2. The figure shows, per environmental category, the relative contributions of all the design variations considered. In this way, differences in the contributions to environmental impacts introduced by the decision taken to offer a clearer picture of the environmental sustainability for a $1.5-\mathrm{MW}$ wind turbine incorporating different technological advancements on a wind farm can be appreciated. As can be seen, the baseline turbine has higher contributions to impacts compared to TIOs 1-4 in the categories ODP, MAETP, HTP and TETP. It is equivalent in FAETP contributions with TIO 1 and has lower contributions to ADP-41.6\% lower than TIO 2, AP-15.6\% lower than TIO 2, EP- $0.14 \%$ lower than TIO 1, GWP-40.7\% lower than TIO 2 and POP-1.2\% lower than TIO 1. With the incorporation of the technological advancements, the materials used in the wind turbine components and their associated masses are varied. For TIO 1, compared to the baseline turbine, the contribution to impacts increased for five environmental categories ADP-6.6\% higher, AP-2.4\% higher, EP-0.14\% higher, GWP-5.9\% higher and POP-1.2\% higher, due to its higher material mass. TIO 2 showed an increase in contributions to three environmental categories, ADP-41.6\% higher, AP-16\% higher and GWP-40.7\% higher, compared to the baseline turbine. Lower contributions to all the environmental categories were observed for TIO 3 compared to the baseline turbine, as well as increased contributions towards ADP $-37 \%$ higher, and GWP-34.8\% higher, for TIO 4 compared to the baseline turbine.

Since higher tower height generally improves access to wind resource, TIOs 2 and 4 experience higher capacity factors compared to the other designs. However, the comparison of TIOs 2 and 4 to the baseline turbine shows the disadvantage of both designs with respect to ADP and GWP.
The higher capacity factors experienced by the wind farm using TIO 2 and TIO 4 did not offset the higher environmental costs as a result of the increased use of glass-reinforced nylon in both designs. However, TIOs 2 and 4 have lower contributions to the environmental categories EP, ODP, MAETP, FAETP, HTP, POP and TETP compared to the baseline turbine. The exception is AP where TIO 2 has a $13.8 \%$ higher contribution and TIO 4 has a $13.4 \%$ lower contribution compared to the baseline turbine. The main life cycle impacts of the analysed wind farm occur during the construction stage. In view of this, glass-reinforced nylon, steel and copper are the materials with the highest contributions to impacts due to their large quantity and high energy/ emission intensity. Other significant contributors to impacts are caused by fibre glass and concrete (due to its sheer tonnage). Despite the high energy/emissions intensity of aluminium, impacts related to its usage are less notable because of its relatively small mass.

\section{Life cycle interpretation}

This section presents a comprehensive discussion of the baseline turbine and TIOs for the different life cycle stages as well as the comparison with existing literature.

\section{Construction stage}

According to the contribution analysis of the different life cycle stages to the life cycle impacts of the wind farm, the construction stage is the major contributor to the life cycle impacts across all the studied cases. The environmental impacts of the construction stage for the baseline turbine are compared to that of TIOs $1-4$. Figure 3 shows the characterised impact assessment results of the comparison.

Four of the impacts from the baseline turbine, ODP, HTP, MAETP and TETP, are higher than for TIOs 1-4, ranging
Fig. 2 Characterisation results for life cycle environmental impacts of the baseline turbine compared to TIOs $1-4$

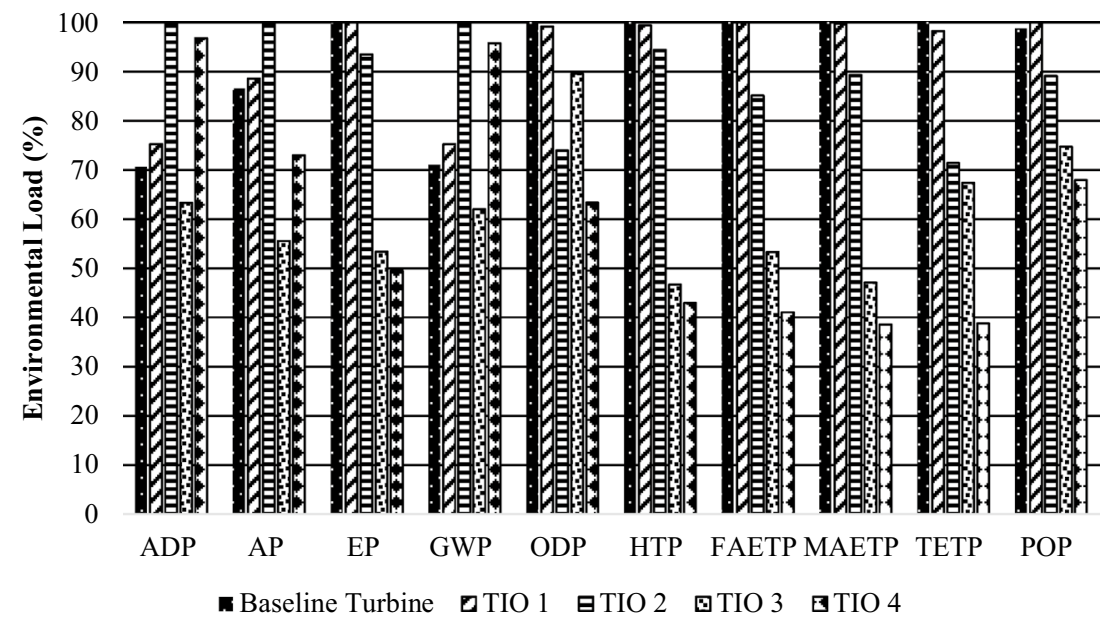


Fig. 3 Characterisation results for the construction stages of the baseline turbine compared to TIOs $1-4$

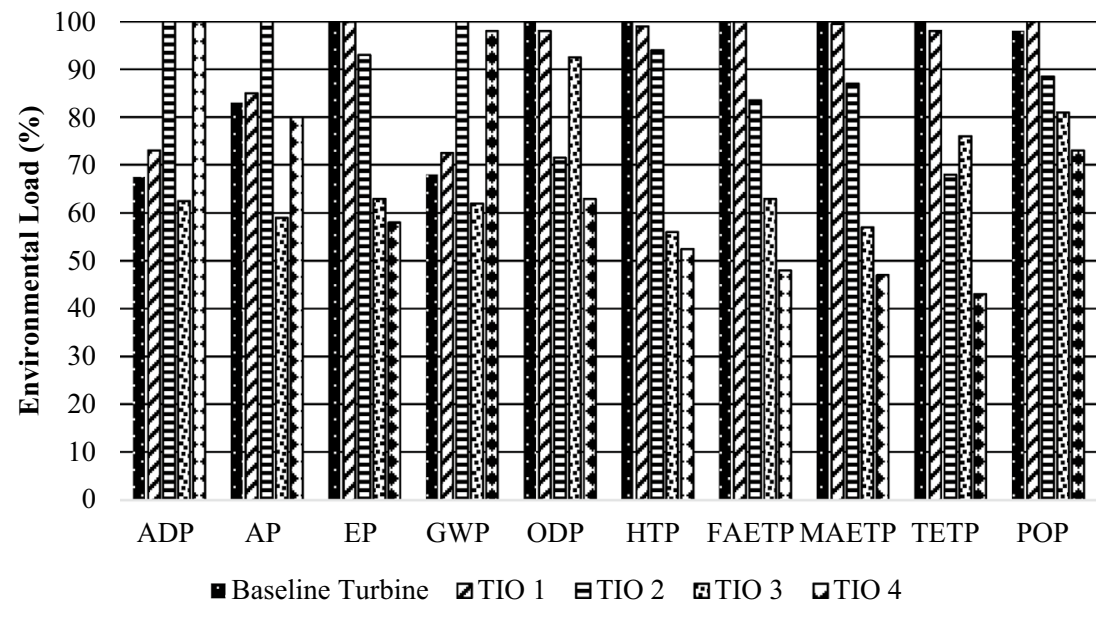

emission intensity of glass-reinforced nylon as well as higher weight due to the tower height increase. The other impacts EP, ODP, HTP, FAETP, MAETP, TETP and POP range from 5.8 to $31.8 \%$ lower for TIO 2. It can thus be said that in the construction stage, TIO 2 is less environmentally sustainable than the baseline turbine for three environmental categories.

\section{TIO 3 in the construction stage}

ODP, POP and TETP are the impacts with the highest contributions for TIO 3. However, none of these impacts are higher than for the baseline turbine but instead range from 7.8 to $31.8 \%$ lower. The reason for this is the $78 \%$ reduction in generator mass as a result of iron use in the rotors instead of copper. Iron is a less energy-intensive material compared to copper resulting in a decrease in the environmental implications across all of the impact categories. Therefore, in the construction stage, TIO 3 is more environmentally sustainable than the baseline turbine for all of the environmental categories.

\section{TIO 4 in the construction stage}

For TIO 4, ADP and GWP are the impacts with the highest contributions and are 30.4 and $32.2 \%$ higher, respectively, compared to the baseline turbine. The reason for this could be attributed to the production of glass-reinforced nylon as a result of its use in the blade and tower. The environmental impact from glass-reinforced nylon, though a significant contributor to ADP and GWP, is offset in the remaining environmental categories by the lower environmental footprint of iron due to the reduced generator mass. As a result, TIO 4 is less environmentally sustainable than the baseline turbine for two environmental categories in the construction stage. 


\section{Operation stage}

The operation stage was the second largest contributor to the life cycle impacts across most of the studied cases. Figure 4 shows the characterised impact assessment results of the comparison. As shown, all of the contributions to impacts from the baseline turbine and TIO 1 are higher compared to contributions from TIOs 2, 3 and 4.

\section{TIO 1 in the operation stage}

The similar contributions of the baseline turbine and TIO 1 across all the environmental categories can be attributed to the similar inputs as regards the material masses used for the generator replacements as well as transportation and energyrelated processes. For the most part, majority of the impacts from both designs are due to the production of copper and steel used for manufacture of the generators during renewal of half of the generators in the operational life of the wind farm. The baseline turbine and TIO 1 are therefore the least environmentally sustainable designs in the operation stage.

\section{TIO 2 in the operation stage}

For TIO 2, similar contributions of $95.5 \%$ can be observed across all the environmental categories. Despite similar inputs for the generator replacements, energy and transportation processes with the baseline turbine and TIO 1, there is a $4.5 \%$ reduction in the results for all the environmental categories. This can be attributed to the influence of capacity factor on environmental impact assessment results. According to Weinzettel et al. (2009), Demir and Taşkin (2013) and Greening and Azapagic (2013), the environmental impact for one functional unit decreases with a higher capacity factor because the energy output is directly related to the environmental sustainability of a wind turbine when measured per $\mathrm{kWh}$ of electricity generated. Hence, the difference in the contribution of TIO 2 to the environmental categories compared to the baseline turbine and TIO 1 can be attributed to the $22 \%$ capacity factor calculated for the wind farm using TIO 2 compared to $21 \%$ for the wind farm using the baseline turbine and TIO 1. Majority of the impacts for TIO 2 are attributed to copper and steel production as explained for the baseline turbine and TIO 1. It can hence be said that TIO 2 is more environmentally sustainable than the baseline turbine and TIO 1 in the operation stage.

\section{TIO 3 and TIO 4 in the operation stage}

As shown, all the contributions to impacts for TIO 3 are lower than contributions from the baseline turbine, TIO 1 and TIO 2 ranging from 60 to $99 \%$ lower. The contributions to impacts for TIO 3 are, however, higher than contributions for TIO 4 across all the environmental categories ranging from 0.05 to $1.8 \%$ higher. This is despite having the same energy, transport and generator material inputs with TIO 4. The generators used for modelling component replacement in TIOs 3 and 4 have a $78 \%$ reduced mass due to iron use in the rotors instead of copper as highlighted in the construction stage. This explains the disparity in results for the contributions to impacts of TIO 3 and TIO 4 as compared to the baseline turbine, TIO 1 and TIO 2. The differences in the contributions to impacts for TIO 3 and TIO 4 can again be attributed to the capacity factors calculated for the wind farm using both turbine designs. The capacity factors calculated for TIOs 3 and 4 are 21 and 22\%, respectively, explaining the lower contributions of TIO 4 compared to TIO 3 for all the environmental categories. Majority of the impacts from both designs are due to the production of steel and electricity mix used during manufacture of the generators. TIO 4 can therefore be said to be the most environmentally sustainable design in the operation stage.
Fig. 4 Characterisation results for the operation stages of the baseline turbine compared to TIOs 1-4

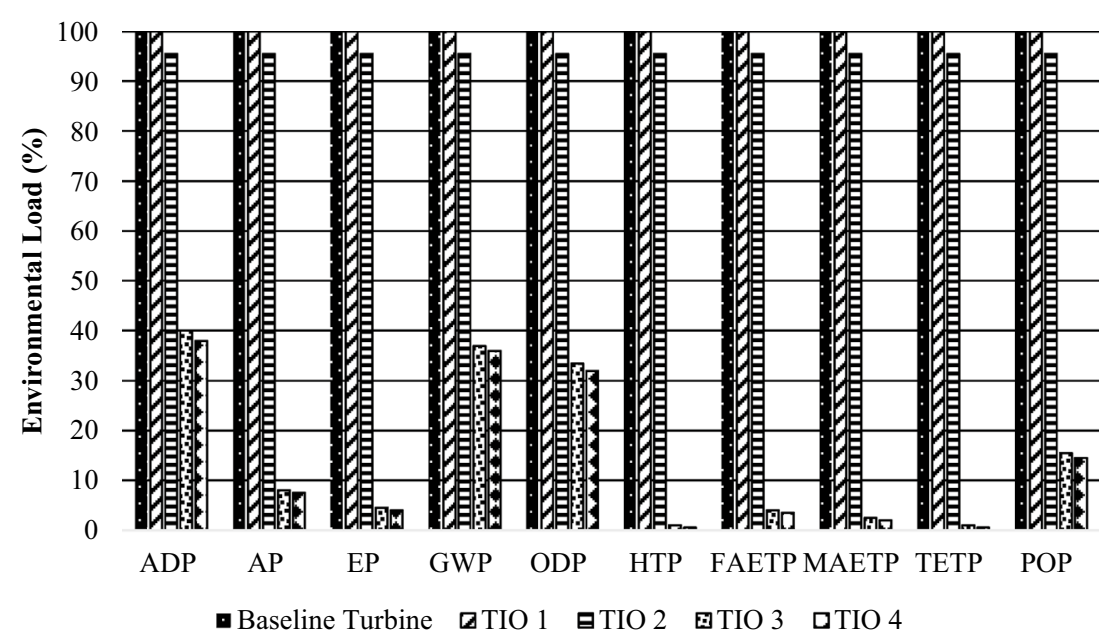




\section{Decommissioning stage}

The decommissioning stage was the lowest contributor to the life cycle impacts across most of the studied cases. Characterised impact assessment results of the comparison are shown in Fig. 5.

- For the baseline turbine, none of its contributions to the environmental categories are higher than contributions from TIO 1 (which has the highest for all the environmental categories). The impacts range from 0.2 to $0.6 \%$ lower for the baseline turbine. The reason for this is the larger mass per wind farm of TIO 1 compared to the baseline turbine. The material composition of the baseline turbine amounts to a total mass per wind farm of $21,987 \mathrm{t}$ (including grid connection but excluding foundation mass) compared to $22,116 \mathrm{t}$ for TIO 1 . It can thus be said that TIO 1 is the least environmentally sustainable design in the decommissioning stage.

- TIO 2 has lower contributions for all the environmental categories compared to the baseline turbine and TIO 1. These contributions range from 11.8 to $24.3 \%$ lower for TIO 2. This can be attributed to the lower mass of TIO 2 $(17,480 t$ per wind farm due to the tower mass reduction of $38 \%$ ) compared to $21,987 \mathrm{t}$ and $22,116 \mathrm{t}$ for the baseline turbine and TIO 1, respectively. TIO 2 is therefore more environmentally sustainable than the baseline turbine and TIO 1 in the decommissioning stage.

- All contributions to the environmental categories for TIO 3 are lower than contributions from the baseline turbine and TIO 1 ranging from 4.2 to $11.4 \%$ lower. The reason for the lower contributions is the 19,570 ton mass per wind farm due to the generator mass reduction described in the construction stage. TIO 3 can hence be said to be more environmentally sustainable than the baseline turbine and TIO 1, but less environmentally sustainable compared to TIO 2.

- TIO 4 has the least contributions towards all the environmental categories compared to the other designs ranging from 15 to $33 \%$ lower. This can be attributed to TIO 4 having the smallest mass per wind farm $(15,428 \mathrm{t}) \mathrm{com}$ pared to the other turbine designs. TIO 4 is therefore the most environmentally sustainable design for all the environmental categories in the decommissioning stage. The causes of the impacts across all the studied cases are largely due to the electricity mix used during the dismantling of components, component transportation and crane use during the disassembly process.

\section{Comparison of results with the literature}

A number of wind farm LCA studies have been carried out in western European locations. They are:

- (Vestas 2006), 300-MW onshore farm consisting of V821.65-MW turbines;

- (PE 2011), 100-MW onshore farm composed of 3-MW V112 turbines;

- (Garrett and Rønde 2013), 50-MW onshore farm comprising 2-MW Grid Streamer turbines;

- (Vestas 2013), 90-MW onshore farm composed of V903.0-MW turbines;

- (Vestas 2014), 100-MW onshore farm consisting of V126-3.3-MW turbines.

A direct comparison of the results between them is, however, problematic due to the different assumptions made which generally include energy outputs, wind class, capacity factors, turbine capacities and differing designs. In all of the studies, the focus has been on Vestas wind turbines
Fig. 5 Characterisation results for the decommissioning stages of the baseline turbine compared to TIOs $1-4$

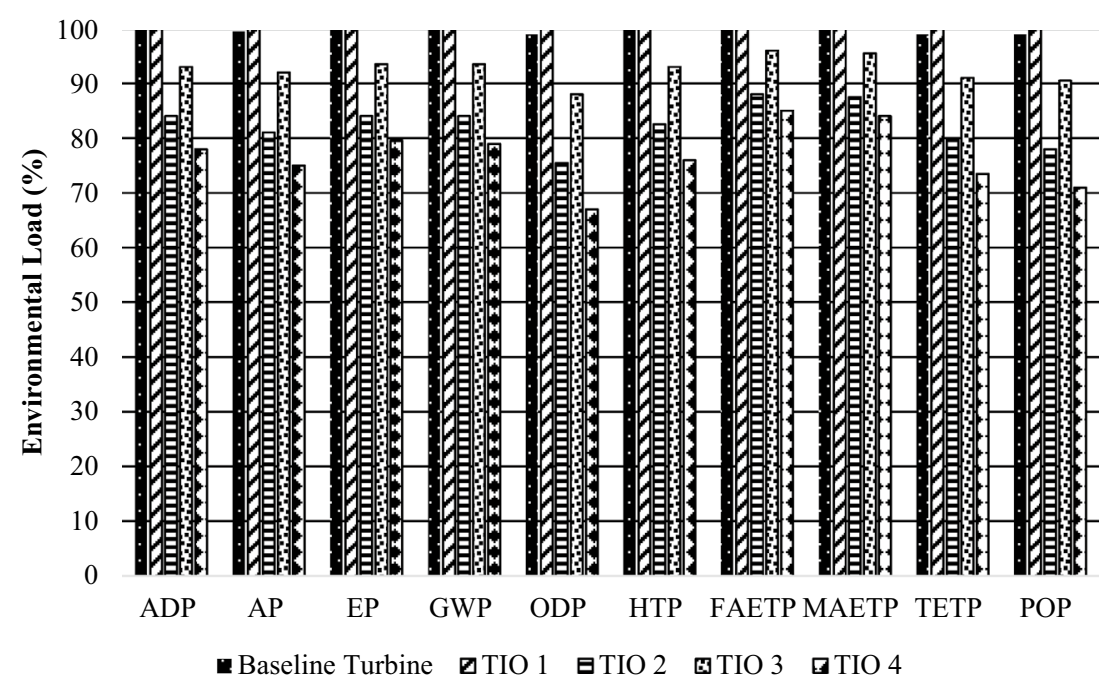


with rated capacities between 1.65 and 3.3 MW. For these reasons, as illustrated in Fig. 6, environmental impacts of the wind farms described in the various studies vary. For example, GWP ranges from 6.2 to $8.2 \mathrm{~g} \mathrm{CO}_{2}$ eq. $/ \mathrm{kWh}$ for the different capacities and designs. At between 10.3 and $16.6 \mathrm{~g}$ $\mathrm{CO}_{2}$ eq. $/ \mathrm{kWh}$, the GWPs estimated in this study for the baseline turbine and TIOs are higher than this range. As there are no studies for the $1.5 \mathrm{MW}$ capacity, the closest turbine size available is $1.65 \mathrm{MW}$ for which the GWP is estimated at $7.1 \mathrm{~g} \mathrm{CO}_{2}$ eq./kWh. Apart from the different rated capacities and designs used in the Vestas studies, the major reason for the difference in results is the fact that recycling of materials in the decommissioning stage is not considered in this study.

According to Davidsson et al. (2012), the environmental impacts embodied in a wind turbine are reduced by
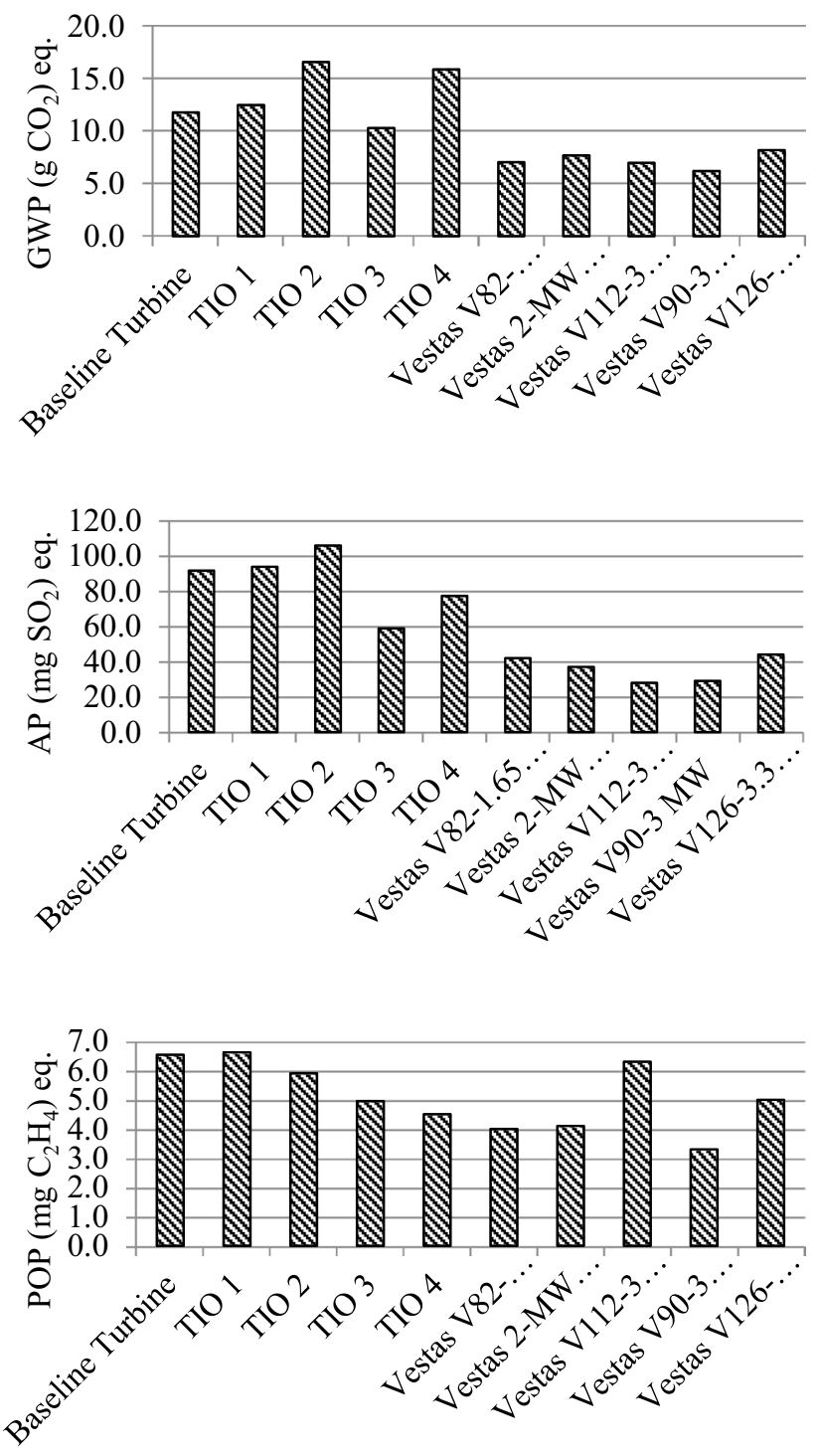

Fig. 6 Estimated GWP, AP and POP for the wind farm using the different design variations compared with the literature approximately half through end-of-life recycling. This is highlighted in Tremeac and Meunier (2009) and Chen et al. (2011) where a $26-27 \%$ reduction in total environmental indicator values is observed. Similar differences are observed for AP, with the exception of POP, for which the Vestas V112-3-MW and V126-3.3-MW turbines have impact contributions comparable to results obtained in this study, i.e. $6.3 \mathrm{mg} \mathrm{C}_{2} \mathrm{H}_{4}$ eq./kWh and $5 \mathrm{mg} \mathrm{C}_{2} \mathrm{H}_{4}$ eq./kWh, respectively. This can be attributed to the higher contribution of the manufacturing stages for the V112-3-MW and V1263.3-MW turbines towards POP compared to the other Vestas turbines. As volatile organic compounds (VOCs) emissions from steel and aluminium production processes contribute significantly towards POP in the two studies, it suggests that Vestas factory operations within the manufacturing stage for the V112-3-MW and V126-3.3-MW turbines have a larger contribution to this impact compared to the other Vestas turbines. The difference may also relate to LCI datasets being used, i.e. age of data and difference between Ecoinvent and $\mathrm{GaBi}$ databases from the different studies. The comparison also suggests that there is no obvious relationship between wind turbine capacity and contribution to environmental impacts although typically, larger wind turbines have lower GWP compared to smaller scale installations. For example according to Amor et al. (2010), a 1-kW turbine generates $2314 \mathrm{kWh} / \mathrm{a}$ with a GWP of $160 \mathrm{~g} \mathrm{CO}_{2}$ eq./kWh. In contrast, a 4.5-MW turbine produces $1.7 \mathrm{GWh} / \mathrm{a}$ while having a GWP of $9 \mathrm{~g} \mathrm{CO}_{2}$ eq./kWh (Tremeac and Meunier 2009). Wind class is also shown to have an effect on GWP for new turbine designs. It can be observed that, generally, higher wind class turbines have lower GWP per kWh due to higher energy of the wind, lower tower heights and shorter blades compared to lower wind turbine configurations. Therefore, the findings from the wind farm modelled using the baseline turbine and TIOs 1-4 suggest that given end-of-life recycling was not considered, the life cycle impacts compare well with the Vestas wind farm studies.

\section{Economic assessment}

The economic analysis encompasses the estimation of capital and operational expenditure for the wind farm using the different turbine design variations. Additionally, the payback times for the wind farm using the different turbine designs have been estimated as shown in Table 8. The NREL study by Fingersh et al. (2006) investigated the costs of wind turbines using simple scaling relationships to estimate the cost of wind turbine subsystems and components for different configurations and sizes of components. The cost formulas in the model are a direct function of tower height, machine rating, rotor diameter or a combination of these factors. The overall cost model created to estimate the cost of the wind farm in this study includes 
Table 8 Life cycle costs of the wind farm using the different turbine design variations

\begin{tabular}{llllll}
\hline & Baseline turbine & TIO 1 & TIO 2 & TIO 3 & TIO 4 \\
\hline Capital investment (million £) & $50.795 \mathrm{M}$ & $59.033 \mathrm{M}$ & $94.130 \mathrm{M}$ & $43.701 \mathrm{M}$ & $84.939 \mathrm{M}$ \\
Revenue (million £/year) & $17.548 \mathrm{M}$ & $17.548 \mathrm{M}$ & $17.774 \mathrm{M}$ & $17.548 \mathrm{M}$ & $17.774 \mathrm{M}$ \\
O\&M (million £/year) & $2.200 \mathrm{M}$ & $2.200 \mathrm{M}$ & $2.218 \mathrm{M}$ & $2.200 \mathrm{M}$ & $2.218 \mathrm{M}$ \\
Payback time (years) & 3.3 & 3.8 & 6.1 & 2.8 & 5.5 \\
\hline
\end{tabular}

13 separate sub-models which estimate the costs of individual system components.

It can be seen that the design variation selected can make a difference in the length of the payback period. Comparing the turbine designs, the payback time for the most advantageous design variation (TIO 3 ) is 2.8 years versus 6.1 years for the design variation with the longest payback time (TIO 2). When comparing the turbine designs at different tower heights, TIO 2 and TIO 4 with higher hub heights had longer payback periods. This suggests that the expected annual revenue and capital investment cost contribute significantly to the payback period for the two designs. The economic assessment provides insight into the use of the different design variations on the wind farm and demonstrates how capital investment for the different design variations results in differing payback time results. Analysis of the different turbine designs revealed that capital investment cost is the most significant factor influencing the economic success of the turbine designs. Capital investment is most significant because even with higher annual revenue and O\&M costs for TIO 2 and TIO 4, the trend in payback time results for the baseline turbine and TIOs 1-4 was similar to the capital investment cost results. Larger capital investment costs increase the time needed to pay back the initial investment. It should, however, be noted that the higher capital investment associated with incorporating carbon fibre materials in the tower is not worth the added cost since the design variations with the longest payback periods were shown to be TIO 2 and TIO 4. This economic assessment also demonstrates the importance of using technological advancements to improve the revenue of the wind farm. Expected annual revenue of the wind farm using TIO 2 and TIO 4 is $£ 17.774 \mathrm{M}$ compared to $£ 17.548 \mathrm{M}$ for the baseline turbine. The higher tower heights of TIO 2 and TIO 4 improved access to wind resource and hence the associated revenue. Hence, when comparing the payback time of the wind farm using the different design variations, the results were quite clear. With the incorporation of the technological advancements, TIO 3 is the most advantageous design option for the wind farm.

\section{Conclusions, limitations and further work}

In this paper, the environmental sustainability of a $1.5-\mathrm{MW}$ wind turbine incorporating different technological advancements on a wind farm is examined through case studies. In order to evaluate the environmental performance of the wind farm, first, the wind farm was modelled using the baseline turbine and TIOs $1-4$. Then for TIOs $1-4$, the life cycle effects on the environmental categories are investigated and compared against the baseline turbine. In performing the life cycle modelling of the wind farm using TIOs 2 and 4, the effect of improved capacity factor is considered. With the results obtained, the following conclusions are drawn.

- Firstly, with respect to the life cycle environmental impacts of the wind farm using the baseline turbine, four environmental categories are higher compared to TIOs $1-4$ ranging from $0.3 \%$ higher MAETP for TIO 1 to $61.2 \%$ higher TETP for TIO 4 . The result suggests that the baseline turbine is less environmentally sustainable than TIOs 1-4 for four out of ten environmental categories. In other words, a strong argument could be made to advocate for the use of the baseline turbine as it compares favourably with TIOs 1-4.

- Secondly, similar conclusions can be drawn in terms of incorporation of the technological advancements. The contribution to ADP, AP, EP, GWP and POP between TIOs 1, 2 and 4 increased compared to the baseline turbine due to higher material masses as well as environmental characteristics of the materials used. TIO 3, however, showed lower contributions for all the environmental categories compared to the baseline turbine. Hence, it is shown that a strong relationship exists between material mass and environmental characteristics of the materials used.

- Thirdly, when comparing the life cycle environmental impacts of TIOs 2 and 4 with the baseline turbine, the results are considerably less clear. Even with the higher capacity factors experienced using both designs, the environmental impacts due to the increased use of glassreinforced nylon were not offset for the environmental categories ADP and GWP compared to the baseline turbine. It is highlighted in Hammond and Jones (2011) that steel has embodied energy and embodied carbon values of $24.4 \mathrm{MJ} / \mathrm{kg}$ and $1.77 \mathrm{kgCO}_{2} / \mathrm{kg}$, respectively. Glassreinforced nylon, however, has embodied energy and embodied carbon values of $138.6 \mathrm{MJ} / \mathrm{kg}$ and $6.5 \mathrm{kgCO}_{2} /$ $\mathrm{kg}$. Hence, it can be said that based on the same tower height and lower tower mass of TIO 2 and TIO 4 due to glass-reinforced nylon use, the environmental impact of 
the steel tower in the baseline turbine will not exceed that of the towers in TIO 2 and TIO 4. This is due to the fact that the embodied energy and embodied carbon values of glass-reinforced nylon are about five orders of magnitude higher than that of steel. Therefore, when all the criteria are considered, some environmental trade-offs will be required if TIOs 1-4 are to play a role in supplying future grid electricity.

In this work, the authors excluded uncertainty and sensitivity analysis and focused on the evaluation of environmental impacts for technology improvement opportunities in wind turbine design. Uncertainty and sensitivity analysis are, however, important in conducting LCA studies. Uncertainty is one of the characteristics of the real world and hence including uncertainty and sensitivity analysis could help achieve more realistic results (Heath et al. 2015). Therefore, additional future work should include sensitivity analysis on wind farm life time, capacity factor, effect of weight difference using NREL baseline equations compared to Enercon E-66 used in this study and the adoption of different methods such as Monte Carlo or exploratory modelling. It is relevant to note here that the current study is based on the wind turbine technology of 2002 and it is fully recognised that technology has changed significantly over the past one and a half decade. Future studies may conduct comparative LCA on these technological changes in the development of newer wind turbine technologies. This would be another excellent application for the analysis of potential technological advancements in wind energy.

Acknowledgements This research did not receive any specific grant from funding agencies in the public, commercial or not-for-profit sectors.

Open Access This article is distributed under the terms of the Creative Commons Attribution 4.0 International License (http://creativecommons.org/licenses/by/4.0/), which permits unrestricted use, distribution, and reproduction in any medium, provided you give appropriate credit to the original author(s) and the source, provide a link to the Creative Commons license, and indicate if changes were made.
Table 9 LCI of the Enercon E-66 wind turbine (Papadopoulos 2010)

\begin{tabular}{|c|c|c|c|c|}
\hline & \multicolumn{4}{|l|}{ BOM } \\
\hline & Material & Mass & Unit & Total \\
\hline \multirow[t]{11}{*}{3 Blades } & Aluminium & 99 & $\mathrm{~kg}$ & \\
\hline & Fibre glass & 6564 & $\mathrm{~kg}$ & \\
\hline & Epoxy resin & 4548 & $\mathrm{~kg}$ & \\
\hline & Hardener & 1575 & $\mathrm{~kg}$ & \\
\hline & Polyamide & 228 & $\mathrm{~kg}$ & \\
\hline & Polyethene & 684 & $\mathrm{~kg}$ & 16,152 \\
\hline & PVC foam & 837 & $\mathrm{~kg}$ & \\
\hline & PVC & 393 & $\mathrm{~kg}$ & \\
\hline & Paint & 552 & $\mathrm{~kg}$ & \\
\hline & Rubber & 165 & $\mathrm{~kg}$ & \\
\hline & Others (iron) & 507 & $\mathrm{~kg}$ & \\
\hline \multirow[t]{3}{*}{ Tower } & Steel & 14,4182 & $\mathrm{~kg}$ & \\
\hline & Galvanised steel & 4695 & $\mathrm{~kg}$ & 153,094 \\
\hline & Paint & 4217 & $\mathrm{~kg}$ & \\
\hline \multirow[t]{7}{*}{ Generator } & Copper & 8988 & $\mathrm{~kg}$ & \\
\hline & Steel sheet & 17,927 & $\mathrm{~kg}$ & \\
\hline & Steel (no alloy) & 13,258 & $\mathrm{~kg}$ & \\
\hline & $\begin{array}{l}\text { Steel (galvanised, low } \\
\text { grade) }\end{array}$ & 105 & $\mathrm{~kg}$ & 40,690 \\
\hline & $\begin{array}{l}\text { Steel (alloy, high } \\
\text { grade) }\end{array}$ & 14 & $\mathrm{~kg}$ & \\
\hline & Paint & 150 & $\mathrm{~kg}$ & \\
\hline & Others & 248 & $\mathrm{~kg}$ & \\
\hline \multirow[t]{12}{*}{ Rest of nacelle } & Steel (no alloy) & 10,780 & $\mathrm{~kg}$ & \\
\hline & Steel (alloy, low grade) & 9101 & $\mathrm{~kg}$ & \\
\hline & $\begin{array}{l}\text { Steel (galvanised, low } \\
\text { grade) }\end{array}$ & 1224 & $\mathrm{~kg}$ & \\
\hline & Cast steel & 3708 & $\mathrm{~kg}$ & \\
\hline & Cast iron & 21,027 & $\mathrm{~kg}$ & \\
\hline & Aluminium & 127 & $\mathrm{~kg}$ & 51,591 \\
\hline & Copper & 293 & $\mathrm{~kg}$ & \\
\hline & Fibre glass & 924 & $\mathrm{~kg}$ & \\
\hline & $\begin{array}{l}\text { Unsaturated polyester } \\
\text { resin }\end{array}$ & 2159 & $\mathrm{~kg}$ & \\
\hline & Electronics & 120 & $\mathrm{~kg}$ & \\
\hline & Paint & 504 & $\mathrm{~kg}$ & \\
\hline & Others & 1624 & $\mathrm{~kg}$ & \\
\hline
\end{tabular}

\section{Appendix}

See Table 9. 
Table 9 (continued)

\begin{tabular}{|c|c|c|c|c|}
\hline & \multicolumn{4}{|l|}{ BOM } \\
\hline & Material & Mass & Unit & Total \\
\hline \multirow[t]{13}{*}{ Grid connection } & Steel sheet & 1300 & $\mathrm{~kg}$ & \\
\hline & Steel (alloy, low grade) & 927 & $\mathrm{~kg}$ & \\
\hline & $\begin{array}{l}\text { Steel (alloy, high } \\
\text { grade) }\end{array}$ & 630 & $\mathrm{~kg}$ & \\
\hline & Steel (galvanised) & 715 & $\mathrm{~kg}$ & \\
\hline & Steel (for construction) & 741 & $\mathrm{~kg}$ & \\
\hline & Iron & 1042 & $\mathrm{~kg}$ & \\
\hline & Copper & 6119 & $\mathrm{~kg}$ & 27,734 \\
\hline & PVC & 747 & $\mathrm{~kg}$ & \\
\hline & Gear oil & 940 & $\mathrm{~kg}$ & \\
\hline & Rest of electrics & 1065 & $\mathrm{~kg}$ & \\
\hline & Electronics & 1283 & $\mathrm{~kg}$ & \\
\hline & Light weight concrete & 12,000 & $\mathrm{~kg}$ & \\
\hline & Others & 225 & $\mathrm{~kg}$ & \\
\hline \multirow[t]{4}{*}{ Deep foundations } & Normal concrete & 575,000 & $\mathrm{~kg}$ & \\
\hline & Steel (construction) & 26,300 & $\mathrm{~kg}$ & 614,709 \\
\hline & Steel (no alloy) & 13,243 & $\mathrm{~kg}$ & \\
\hline & PVC & 166 & $\mathrm{~kg}$ & \\
\hline
\end{tabular}

\section{References}

Allaei D, Andreopoulos Y (2014) INVELOX: Description of a new concept in wind power and its performance evaluation. Energy 69:336-344. https://doi.org/10.1016/j.energy.2014.03.021

Amor MB, Lesage P, Pineau PO, Samson R (2010) Can distributed generation offer substantial benefits in a Northeastern American context? A case study of small-scale renewable technologies using a life cycle methodology. Renew Sustain Energy Rev 14(9):28852895. https://doi.org/10.1016/j.rser.2010.08.001

Ardente F, Beccali M, Cellura M, Brano VL (2008) Energy performances and life cycle assessment of an Italian wind farm. Renew Sustain Energy Rev 12(1):200-217. https://doi.org/10.1016/j. rser.2006.05.013

Arvesen A, Hertwich EG (2011) Environmental implications of large-scale adoption of wind power: a scenario-based life cycle assessment. Environ Res Lett 6(4):045102. https://doi. org/10.1088/1748-9326/6/4/045102

Bai CJ, Chen PW, Wang WC (2016) Aerodynamic design and analysis of a $10 \mathrm{~kW}$ horizontal-axis wind turbine for Tainan, Taiwan. Clean Technol Environ Policy 18(4):1151-1166. https://doi.org/10.1007/ s10098-016-1109-z

Chataignere A, Boulch D (2003) Wind turbine (WT) systems, ECLIPSE-environmental and ecological life cycle inventories for present and future power systems in Europe. Final Report. http://www.eclipse-eu.org/pubres_guide.html. Accessed 26 Oct 2014

Chen GQ, Yang Q, Zhao Y (2011) Renewability of wind power in China: a case study of nonrenewable energy cost and greenhouse gas emission by a plant in Guangxi. Renew Sustain Energy Rev 15(5):2322-2329. https://doi.org/10.1016/j.rser.2011.02.007

Cohen JT, Schweizer A, Laxson S, Butterfield S, Schreck L, Fingersh P, Veers P, Ashwill T (2008) Technology improvement opportunities for low wind speed turbines and implications for cost of energy reduction. Natl Renew Energy Lab, Golden, Colorado (US), Technical Report NREL/TP-500-41036

Crawford R (2009) Life cycle energy and greenhouse emissions analysis of wind turbines and the effect of size on energy yield. Renew Sustain Energy Rev 13(9):2653-2660. https://doi.org/10.1016/j. rser.2009.07.008

Davidsson S, Höök M, Wall G (2012) A review of life cycle assessments on wind energy systems. Int J Life Cycle Assess 17(6):729_ 742. https://doi.org/10.1007/s11367-012-0397-8

Demir N, Taşkın A (2013) Life cycle assessment of wind turbines in Pınarbaş1-Kayseri. J Clean Prod 54:253-263. https://doi. org/10.1016/j.jclepro.2013.04.016

Dolan SL, Heath GA (2012) Life cycle greenhouse gas emissions of utility-scale wind power. J Ind Ecol 16(s1):S136-S154. https:// doi.org/10.1111/j.1530-9290.2012.00464.x

D'Souza N, Gbegbaje-Das E, Shonfield P (2011) Life cycle assessment of electricity production from a Vestas V112 turbine wind plant. Copenhagen: PE North West Europe ApS; 2011 February. Final report. https://www.vestas.com/ /media/vestas/about/sustainability/pdfs/lca_v112_study_report_2011.pdf. Accessed 12 Nov 2016

Duflou JR, Deng Y, Van Acker K, Dewulf W (2012) Do fiber-reinforced polymer composites provide environmentally benign alternatives? A life-cycle-assessment-based study. MRS Bull 37(04):374-382

Elsam (2004) Life cycle assessment of offshore and onshore sited windfarms. Doc. no. 200128. Elsam Engineering A/S, Denmark. http:// www.vestas.com/en/about-vestas/sustainability/wind-turbinesand-theenvironment/life-cycle-assessment-(lca).aspx. Accessed 25 Mar 2016

Fingersh LJ, Hand MM, Laxson AS (2006) Wind turbine design cost and scaling model. Citeseer

Fokaides PA, Miltiadous IC, Neophytou MKA, Spyridou LP (2014) Promotion of wind energy in isolated energy systems: the case of the Orites wind farm. Clean Technol Environ Policy 16(3):477488. https://doi.org/10.1007/s10098-013-0642-2

Garrett P, Rønde K (2013) Life cycle assessment of wind power: comprehensive results from a state-of-the-art approach. Int J Life Cycle Assess 18(1):37-48. https://doi.org/10.1007/ s11367-012-0445-4

Glassbrook KA, Carr AH, Drosnes ML, Oakley TR, Kamens RM, Gheewala SH (2014) Life cycle assessment and feasibility study of small wind power in Thailand. Energy Sustain Dev 22:66-73

Google maps (2014) Pen y Cymoedd wind farm. http://wikimapia. org/\#lat $=55.6912296 \& l o n=-4.2757416 \& \mathrm{z}=13 \& \mathrm{l}=0 \& \mathrm{~m}=\mathrm{s} \& \mathrm{v}=9$. Accessed 1 Oct 2014

Greening B, Azapagic A (2013) Environmental impacts of microwind turbines and their potential to contribute to UK climate change targets. Energy 59:454-466. https://doi.org/10.1016/j. esd.2013.12.004

Guinée JB (2002) Handbook on life cycle assessment operational guide to the ISO standards. Int J Life Cycle Assess 7(5):311-313. https://doi.org/10.1007/BF02978784

Hammond G, Jones C (2011) Inventory of Carbon and energy version 2.0 (ICE V2. 0). Department of Mechanical Engineering, University of Bath, Bath

Heath G, Warner E, Steinberg D, Brandt A (2015) Estimating US methane emissions from the natural gas supply chain: approaches, uncertainties, current estimates, and future studies. Joint Institute for Strategic Energy Analysis, Golden CO. NREL/TP-6A5062820. http://www.nrel.gov/docs/fy16osti/62820.pdf. Assessed 12 Nov 2016

Howarth J, Mareddy SS, Mativenga PT (2014) Energy intensity and environmental analysis of mechanical recycling of carbon fibre composite. J Clean Prod 81:46-50. https://doi.org/10.1016/j. jclepro.2014.06.023 
Igliński B, Piechota G, Iglińska A, Cichosz M, Buczkowski R (2016) The study on the SWOT analysis of renewable energy sector on the example of the Pomorskie Voivodeship (Poland). Clean Technol Environ Policy 18(1):45-61

ISO (2006a) ISO 14040. Environmental management-life cycle assessment-principles and framework (second edition, 200607-01). ISO, Geneva

ISO (2006b) ISO 14044. Environmental management-life cycle assessment-requirements and guidelines (first edition, 200607-01). ISO, Geneva

Kabir MR, Rooke B, Dassanayake GM, Fleck BA (2012) Comparative life cycle energy, emission, and economic analysis of $100 \mathrm{~kW}$ nameplate wind power generation. Renew Energy 37(1):133-141. https://doi.org/10.1016/j.renene.2011.06.003

Lantz E, Wiser R, Hand M (2012) The past and future cost of wind energy. Natl Renew Energy Lab, Golden, CO, Report No. NREL/ TP-6A20-53510

Lenzen M, Schaeffer R (2012) Historical and potential future contributions of power technologies to global warming. Clim Change 112(3-4):601-632. https://doi.org/10.1007/s10584-011-0270-y

Lieberei J, Gheewala SH (2017) Resource depletion assessment of renewable electricity generation technologies - comparison of life cycle impact assessment methods with focus on mineral resources. Int J Life Cycle Assess 22(2):185-198. https://doi.org/10.1007/ s11367-016-1152-3

Lund H (2007) Renewable energy strategies for sustainable development. Energy 32(6):912-919. https://doi.org/10.1016/j. energy.2006.10.017

Martínez E, Sanz F, Pellegrini S, Jiménez E, Blanco J (2009) Life-cycle assessment of a 2-MW rated power wind turbine: CML method. Int J Life Cycle Assess 14(1):52-63. https://doi.org/10.1007/ s11367-008-0033-9

Nuon (2009) Pen y Cymoedd wind farm Non-Technical Summary. http://www.slideshare.net/renewableukcymru/pen-y-cymoeddsupplementary-environmental-information. Accessed 28 Aug 2014

Oebels KB, Pacca S (2013) Life cycle assessment of an onshore wind farm located at the northeastern coast of Brazil. Renew Energy 53:60-70. https://doi.org/10.1016/j.renene.2012.10.026

Ozoemena M, Hasan R, Cheung WM (2016) Analysis of technology improvement opportunities for a 1.5 MW wind turbine using a hybrid stochastic approach in life cycle assessment. Renew Energy 93:369-382. https://doi.org/10.1016/j.renene.2016.03.012

Panagiotidou M, Xydis G, Koroneos C (2016) Spatial inequalities and wind farm development in the Dodecanese Islands-legislative framework and planning: a review. Environments 3(3):18. https:// doi.org/10.3390/environments3030018

Papadopoulos I (2010) Comparative analysis of electricity generating technologies with regards to environmental burdens. Ph.D Thesis, University of Bath, Bath

PE North West Europe ApS (2011) Life cycle assessment of electricity production from a Vestas V112 turbine wind plant.
PE NWE, Copenhagen. http://www.vestas.com/en/about/ sustainability\#!available-reports. Assessed 26 Oct 2016

Pehnt M, Oeser M, Swider DJ (2008) Consequential environmental system analysis of expected offshore wind electricity production in Germany. Energy 33(5):747-759. https://doi.org/10.1016/j. energy.2008.01.007

Raadal HLL, Gagnon IS, Modahl S, Hanssen OJ (2011) Life cycle greenhouse gas (GHG) emissions from the generation of wind and hydro power. Renew Sustain Energy Rev 15(7):3417-3422. https://doi.org/10.1016/j.rser.2011.05.001

Rydh CJ, Jonsson M, Lindahl P (2004) Replacement of old wind turbines assessed from energy, environmental and economic perspectives. Other Inf 38:1-26

SeaRates (2014) Sea Rates Reference book, http://www.searates.com/ reference/portdistance/. Accessed 12 Nov 2016

Shafiee M, Brennan F, Espinosa IA (2016) A parametric whole life cost model for offshore wind farms. Int J Life Cycle Assess 21(7):961975. https://doi.org/10.1007/s11367-016-1075-z

Simons PJ, Cheung WM (2016) Development of a quantitative analysis system for greener and economically sustainable wind farms. J Clean Prod 133:886-898. https://doi.org/10.1016/j. jclepro.2016.06.030

Singh AK, Parida SK (2013) Evaluation of current status and future directions of wind energy in India. Clean Technol Environ Policy 15(4):643-655. https://doi.org/10.1007/s10098-012-0554-6

Tremeac B, Meunier F (2009) Life cycle analysis of 4.5 MW and 250 W wind turbines. Renew Sustain Energy Rev 13(8):21042110. https://doi.org/10.1016/j.rser.2009.01.001

Uihlein A (2016) Life cycle assessment of ocean energy technologies. Int J Life Cycle Assess 21(10):1425-1437. https://doi. org/10.1007/s11367-016-1120-y

Vestas (2006) Life cycle assessment of electricity produced from onshore sited wind power plants based on Vestas V821.65 MW turbines. Vestas Wind Systems A/S, Alsvej 21, 8900 Randers, Denmark. http://www.vestas.com/en/about/ sustainability\#! available-reports. Accessed 26 Oct 2016

Vestas (2013) Life cycle assessment of electricity production from an onshore V90-3.0 MW Wind Plant-30 October 2013, Version 1.1. Vestas Wind Systems A/S, Hedeager 44, Aarhus N, 8200, Denmark. http://www.vestas.com/en/about/sustainability\#!availablereports. Accessed 26 Oct 2016

Vestas (2014) Life cycle assessment of electricity production from an onshore V126-3.3 MW Wind Plant-30 June 2014, Version 1.0. Vestas Wind Systems A/S, Hedeager 44, Aarhus N, 8200, Denmark. http://www.vestas.com/en/about/sustainability\#!availablereports $>$ Accessed 26 Oct 2016

Wang Y, Sun T (2012) Life cycle assessment of $\mathrm{CO}_{2}$ emissions from wind power plants: methodology and case studies. Renew Energy 43:30-36. https://doi.org/10.1016/j.renene.2011.12.017

Weinzettel J, Reenaas M, Solli C, Hertwich EG (2009) Life cycle assessment of a floating offshore wind turbine. Renew Energy 34(3):742-747. https://doi.org/10.1016/j.renene.2008.04.004 